\title{
UJI EFEKTIVITAS TOMAT (Solanum lycopersicum) DALAM PAKAN BUATAN TERHADAP PERTUMBUHAN DAN KELANGSUNGAN HIDUP BENIH IKAN TAWES (Puntius javanicus)
}

\section{TOMATO EFFECTIVENESS TEST (Solanum lycopersicum) ON FEED FOR GROWTH PERFORMANCE AND SURVIVAL RATE TAWES FISH (Puntius javanicus)}

\author{
Yusran Ibrahim $^{1 *}$, Andi Irawan ${ }^{2}$, Farah Diana $^{1}$, Mahendra ${ }^{1}$ \\ ${ }^{1}$ Jurusan Akuakultur, Fakultas Perikanan dan Ilmu Kelautan, Universitas Teuku Umar \\ ${ }^{2}$ Jurusan Perikanan, Fakultas Perikanan dan Ilmu Kelautan, Universitas Teuku Umar \\ *Korespondensi: yusranibrahim@utu.ac.id
}

\begin{abstract}
ABSTRAK
Penelitian ini dilakukan untuk melihat tingkat efektifitas tomat dalam pakan buatan terhadap pertumbuhan dan kelangsungan hidup benih ikan tawes (Puntius javanicus). Rancangan yang digunakan adalah Rancangan Acak Lengkap (RAL) dengan 4 perlakuan dan 3 ulangan. Kontrol (P0), ekstrak tomat (1,25 mg) + pakan FF $9994 \%$ (P1), ekstrak tomat (2,75 mg) + pakan FF 999 4\% P2) dan ekstrak tomat $(3,75 \mathrm{mg})+$ pakan FF 999 4\%. Hasil penelitian menunjukkan pertumbuhan panjang mutlak tertinggi diperoleh $\mathrm{P} 3(4,44 \mathrm{~cm})$ dan terendah $\mathrm{P} 0(2,38 \mathrm{~cm})$, pertumbuhan bobot mutlak tertinggi diperoleh P1 (18,75 gr) dan terendah P0 (11,56 gr), laju pertumbuhan spesifik tertinggi diperoleh P1 (2,96\%) dan terendah P0 (2,48\%), serta kelangsungan hidup tertinggi diperoleh P2 dan P3 (93,33\%) dan terendah diperoleh P0 (46,66\%).
\end{abstract}

Kata kunci: Puntius javanicus, Solanum lycopersicum L, pertumbuhan, kelangsungan hidup.

\section{ABSTRACT}

This study was conducted to see the level of tomato effectiveness in artificial feed on the growth and survival of tawes fish seed (Puntius javanicus). The research design used was Completely Randomized Design (RAL) with 4 treatments and 3 replications. Control (P0), tomato extract $(1,25$ $\mathrm{mg})+$ feed FF 999 4\% (P1), tomato extract (2.75 mg) + feed FF 999 4\% P2) and tomato extract $(3.75 \mathrm{mg})+$ feed FF $9994 \%$. The results showed the highest growth length was P3 $(4.44 \mathrm{~cm})$ and lowest P0 $(2.38 \mathrm{~cm})$, the highest growth weight was P1 $(18.75 \mathrm{gr})$ and the lowest P0 (11.56 gr), the highest specific growth rate was P1 (2.96\%) and lowest P0 (2.48\%), and the highest survival was P2 and P3 (93.33\%) and the lowest was P0 (46.66\%).

Keywords: Puntius javanicus, Solanum lycopersicum L, growth, survival rate.

\section{PENDAHULUAN}

Ikan Tawes merupakan salah satu jenis ikan konsumsi air tawar yang telah banyak dikenal orang, ikan Tawes memiliki nilai ekonomis yang cukup tinggi dan banyak diminati masyarakat, selain rasanya yang lezat juga mengandung protein yang cukup tinggi. Permintaan konsumen akan ikan tersebut pun tidak sedikit, maka kita perlu melakukan suatu usaha untuk menjaga kontinitasnya. Salah satu usaha yang dapat dilakukan yakni melalui kegiatan pembenihan, (Susanto, 2003). Ikan Tawes juga salah satu ikan baru yang populer di Aceh khususnya Pantai Barat. Dilihat dari segi permintaan pasar yang semakin hari semakin meningkat sedangkan ketersedian ikannya masih kurang. Karena Balai Benih

*Fakultas Perikanan dan Ilmu Kelautan, Universitas Teuku Umar 
sendiri belum mampu memenuhi permintaan petani akan benih ikan Tawes.

Salah satu cara untuk meningkatan pertumbuhan dengan cara penambahan tomat yang cukup perlu diberikan karena untuk mengimbangi hilangnya proses pembuatan, penyimpanan dan pencucian selama pemberian pakan. Walaupun dibutuhkan dalam jumlah yang sedikit, tomat mempunyai komposisi atau peranan yang sangat besar dalam proses fisiologis ikan. Tomat menjadi acuan peneliti yang harus didapatkan dari pakan,karena tubuh tidak dapat mensintesisnya. Tomat merupakan sumber yang sangat penting oleh ikan untuk proses metabolisme dalam tubuh untuk pertumbuhan dan reproduksi. Tomat juga berperan sebagai kofaktor reaksi hidroksilase asam-asam amino, sehingga dengan adanya tomat pada pakan, ikan mampu memanfaatkan protein lebih efisien untuk pertumbuhan. Keterkaitan tomat dalam efisiensi transpor asam lemak untuk dioksidasi menjadi energi akan turut mendukung pertumbuhan. Selain itu tomat juga berperan sebagai antioksidan dalam mengurangi perioksidasi dari lemak (Lovell, 1988).

Pakan juga merupakan salah satu faktor terpenting yang berpengaruh terhadap pertumbuhan dan kelangsungan hidup ikan yang akan dibudidayakan. Pemberian pakan yang optimal akan menghasilkan pertumbuhan yang baik. Pertumbuhan dapat terjadi karena terdapat kelebihan energi yang berasal dari pakan setelah dikurangi dengan energi hasil metabolisme dan energi yang terkandung dalam feses (Anggriani et al., 2012), ditambahkan oleh Suwirya et al., (2003) menyatakan bahwa, salah satu diantara nutrisi yang penting untuk pertumbuhan adalah vitamin. Vitamin merupakan peranan dalam metabolisme. Khususnya tomat sangat penting dalam pembentukan kolagen, untuk menghasilkan ikan yang tumbuh secara normal.

Peran tomat dalam pakan adalah untuk meningkatkan daya tahan tubuh pada benih ikan terhadap stres dan dapat meningkatkan kelangsungan hidupnya, karena tomat mempunyai tingkat kompisisi yang tinggi sehingga jika kekurangan komposisi yang tinggi pada pakan dapat menyebabkan perubahan bentuk dan deformasi rangka, yang ditunjukkan dengan nafsu makan hilang, pertumbuhan menurun dan terjadi kematian
(Havler, 1988). Untuk itulah perlu dilakukan pengkajian mengenai pengaruh penambahan tomat dalam pakan buatan untuk mengetahui tingkat efisiensi pemanfaatan pakan serta mengetahui pertumbuhan ikan.

\section{METODE PENELITIAN}

\section{Rancangan Percobaan}

Rancangan yang digunakan adalah Rancangan Acak Lengkap (RAL) dengan 4 perlakuan dan 3 ulangan. Kontrol (P0), ekstrak tomat $(1,25 \mathrm{mg})+$ pakan FF $9994 \%$ (P1), ekstrak tomat $(2,75 \mathrm{mg})+$ pakan FF 999 $4 \% \mathrm{P} 2)$ dan ekstrak tomat $(3,75 \mathrm{mg})+$ pakan FF 999 4\%.

\section{Ikan Uji}

Benih ikan tawes (Puntius javanicus) didapatkan dari petani budidaya UPR Beutong. Selanjutnya ikan yang telah didapat dikumpulkan dalam kelambu (hapa) sebanyak 5 ekor dalam satu kelambu (hapa) di UPR Beutong. Ukuran ikan yang di ambil adalah masa pemeliharaan dikolam selama 12 minggu. Ikan yang telah dikoleksi dari kolam tersebut, dimasukkan kedalam hapa penelitian yang telah disiapkan, guna untuk melihat tingkat kelulusan hidup menggunakan ekstrak tomat (Solanum lycopersicum L).

Pembuatan Ekstrak Tomat dan Pakan Ikan

Pembuatan ekstrak tomat dilakukan dengan cara tomat di iris kecil - kecil, kemudian di blender sampai kecil dan dicampurkan berdasarkan perlakuan yang telah ditentukan. Pada perlakuan P0 tanpa adanya pelakuan, sampel hanya diberikan pellet FF 999 selama proses penelitian sampai dengan selesai.

Tomat disiapan ditimbang kemudian di ekstrak menjadi jus sebanyak $125 \mathrm{mg}$ kemudian lalu campurkan kedalam pakan pellet FF 999 yang sudah di hancurkan, untuk perlakuan (P1), kemudian pakan tersebut dijemur anginkan dalam nampan, dan siap untuk di berikan pada perlakuan yang telah ditentukan. Tomat yang sudah ditimbang di ekstrak menjadi jus sebanyak $275 \mathrm{mg}$ dicampurkan kedalam pakan peller FF 999 untuk perlakuan kedua (P2), kemudian pakan tersebut dijemur anginkan dalam nampan, dan siap untuk diberikan pada perlakuan yang telah ditentukan. Tomat yang sudah di timbang, kemudian di ekstrak menjadi jus 
sebanyak $375 \mathrm{mg}$ dicampurkan kedalam pakan pellet FF 999 untuk perlakuan ketiga (P3), kemudian pakan tersebut dijemur anginkan dalam nampan, dan siap diberikan pada ikan perlakuan ketiga (P3).

\section{Sampling}

Parameter utama berupa tingkat pertumbuahn dan kelangsungan hidup ikan tawes setiap 7 hari sekali. Data tersebut dicatat dengan menentukan berat dan panjang pertumbuhan ikan selama penelitian berlangsung. Sampling ikan dilakukan setiap 1 minggu sekali dengan cara melakukan pengukuran panjang dan berat ikan tawes (Puntius javanicus).

\section{Parameter}

Parameter yang diamati selama penelitian meliputi pertumbuhan panjang mutlak, pertumbuhan bobot mutlak, laju pertumbuhan spesifik (SGR), dan tingkat kelangsungan hidup (SR). Data yang diperoleh selanjutnya dianalisis ragam dengan menggunakan Analysis of Varience (ANOVA) pada selang kepercayaan $95 \%$.

\section{HASIL DAN PEMBAHASAN}

Hasil pertumbuhan panjang mutlak dapat dilihat pada Gambar 1. Berdasarkan hasil uji ANOVA yang diperoleh menunjukkan bahwa pemberian perlakuan tomat dalam pakan buatan berbeda nyata terhadap pertumbuhan panjang mutlak benih ikan tawes. Pertumbuhan panjang mutlak tertinggi, jika dilihat dari ukuran panjang ikan adalah pada perlakuan P3 dan P2.

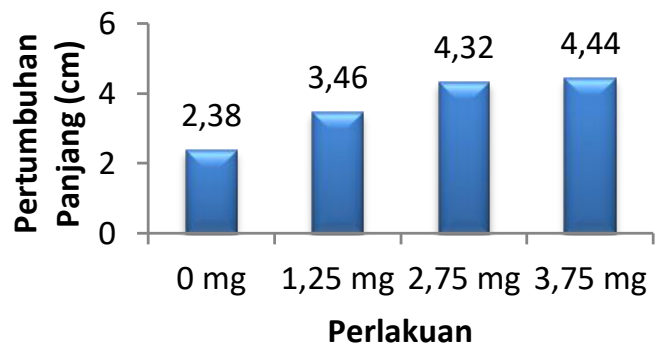

Gambar 1. Pertumbuhan panjang mutlak

\begin{tabular}{llr}
\multicolumn{2}{c}{ Petumbuhan bobot } & mutlak \\
menunjukkan perbedaan yang & nyata \\
antarperlakuan (Gambar & $2)$. & Rata-rata \\
pertumbuhan bobot mutlak yang & tertinggi \\
terdapat pada perlakuan P1 yaitu & sebesar
\end{tabular}

18,75 gram, Sedangkan rata-rata pertumbuhan bobot mutlak yang terendah terdapat pada perlakuan P0 yaitu 11,56 gram.

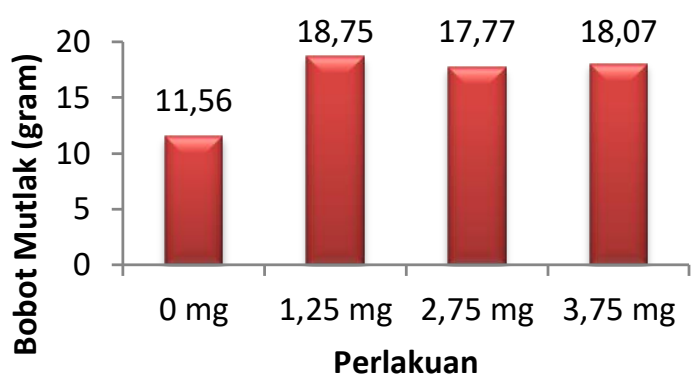

Gambar 2. Pertumbuhan bobot mutlak

Laju pertumbuhan spesifik disajikan pada Gambar 3. Rata-rata pertumbuhan laju pertumbuhan spesifik (SGR) yang tertinggi terdapat pada perlakuan P1 yaitu sebesar $29,68 \%$, Sedangkan rata-rata pertumbuhan bobot mutlak yang terendah terdapat pada perlakuan P0 yaitu 248,52\%.

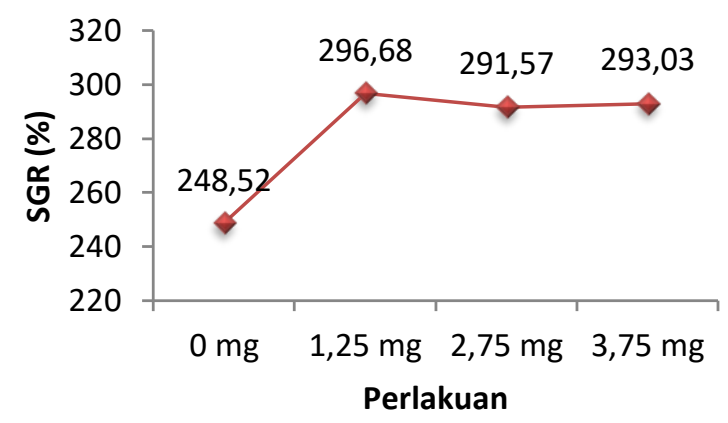

Gambar 3. Laju pertumbuhan spesifik

Kelangsungan hidup (SR) benih ikan tawes yang dipelihara selama 77 hari berada pada kisaran 46,66 - 93,33\% (Gambar 4). Hasil perhitungan ANOVA menunjukan bahwa pemberian perlakuan tomat dalam pakan buatan berpengaruh nyata benih ikan tawes. Nilai SR maksimum terdapat pada perlakuan P2 dan P3 yaitu 93,33\%, diikuti $\mathrm{P} 1$ dengan rata-rata $86,66 \%$ selanjutnya $\mathrm{P} 0$ yaitu $46,66 \%$.

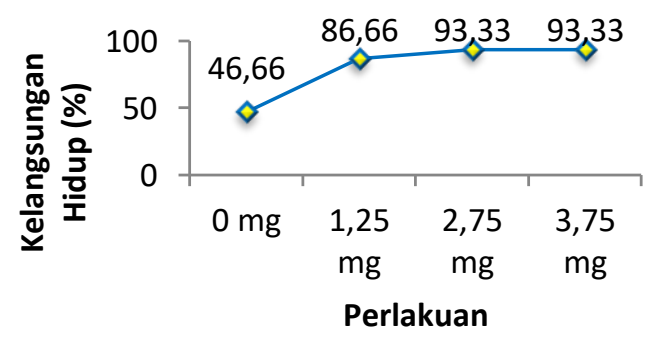

Gambar 4. Kelangsungan hidup 
Hasil penelitian menunjukkan bahwa pertumbuhan panjang mutlak tertnggi secara berurutan adalah $\mathrm{P} 3(4,44), \mathrm{P} 2(4,32), \mathrm{P} 1(3,46)$, dan P0(2,38). Menurut Mulyadi et al (2010) menyatakan bahwa, waktu yang kurang tepat dalam pemberian pakan tidak saja akan menyebabkan kerugian atau pemborosan secara materi, akan tetapi juga akan mempengaruhi atau merusak kualitas air disekitarnya sehingga mempengaruhi kehidupan ikan yang dipelihara. Berdasarkan hasil yang diperoleh menunjukkan bahwa frekuensi pemberian pakan berpengaruh nyata $(\mathrm{P}<0,05)$ terhadap laju pertumbuhan relatif benih tawes, dimana perlakuan panjang dan berat ikan tawes menghasilkan laju pertumbuhan relatif tertinggi.

Hasil penelitian menunjukkan perlakuan P3 dan P2 lebih baik dibandingkan perlakuan yang lain menghasilkan pertumbuhan relative individu tawes tertinggi karena memiliki tingkat konsumsi pakan tertinggi dibandingkan dengan perlakuan P0 dan P1 sehingga lebih banyak asupan nutrisi yang digunakan untuk pertumbuhan. Perlakuan P0 menghasilkan laju pertumbuhan individu empat yang terendah karena hanya mendapatkan pakan asli tanpa ada percampuran dari tomat sehingga jumlah pakan yang dikonsumsi dan dimanfaatkan untuk pertumbuhan lebih sedikit jika dibandingkan dengan perlakuan lainnya. Perlakuan P1 menghasilkan laju pertumbuhan relative yang sedikit dari perlakuan $\mathrm{P} 3$ dan $\mathrm{P} 2$. P0 menunjukkan nilai yang sangat rendah diduga benih ikan tawes sedikit memiliki nafsu makan terhadap perlakuan yang dilakukan selama penelitian berlangsung. Jadi dapat disimpulkan bahwa pemberian pakan dengan campuran tomat sesuai dengan kebutuhan konsumsi pakan untuk benih tawes dapat menghasilkan pertumbuhan yang maksimal, (Mulyadi et al, 2010).

Menurut NRC (1993) menyatakan bahwa pakan yang diberikan harus benarbenar mempertimbangkan kuantitasnya, karena jika pakan yang diberikan terlalu sedikit akan menghasilkan pertumbuhan ikan kurang, sedangkan jika terlalu banyak maka akan menyebabkan metabolisme tidak efisien sehingga tidak tercerna dengan baik dan terbuang yang memungkinkan pencemaran kualitas air, oleh sebab itu frekuensi pemberian pakan yang tepat sangat diperlukan untuk meningkatkan efisiensi pakan. Hasil penelitian menunjukkan seiring dengan meningkatnya tingkat konsumsi pakan maka menyebabkan peningkatan nilai laju pertumbuhan relatif, namun pada batas tertentu peningkatan tingkat konsumsi pakan tidak memberikan peningkatan pertumbuhan karena masing-masing ikan mempunyai tingkat konsumsi pakan optimal, jadi apabila pemberian pakan telah melewati tingkat konsumsi optimal maka pakan tidak dapat dimanfaatkan untuk pertumbuhan melainkan dibuang dalam bentuk feses, (Mulyadi et al, 2010).

Hasil penelitian menujukkan bahwa perlakuan P3 dan p2 lebih baik dibandingkan dengan perlakuan yang lain. Hal ini sama dengan yang dikemukakan oleh Efendi (1992) menyatakan bahwa, pertumbuhan dipengaruhi oleh jenis dan ukuran ikan, makanan, dan kualitas perairan. Dari penelitian yang lain Effendie (1997) juga menyatakan bahwa, pertumbuhan adalah perubahan ukuran baik panjang, bobot maupun volume dalam kurun waktu tertentu, atau dapat juga diartikan sebagai pertambahan jaringan akibat dari pembelahan sel secara mitosis, yang terjadi apabila ada kelebihan pasokan energi dan protein.

Pertumbuhan spesifik rata-rata ikan tawes ditampilkan dalam gambar 6 diatas bahwa ikan tawes yang tertinggi pada penambahan tomat dengan kadar $125 \mathrm{mg} / \mathrm{kg}$ pakan, kemudian diikuti secara berturut-turut dengan kadar tanpa ada perlakuan (kontrol), kemudian diikuti dengan perlakuan 275 $\mathrm{mg} / \mathrm{kg}$ pakan, dan kadar $375 \mathrm{mg} / \mathrm{kg}$ pakan dan yang paling tinggi perlakuannya. Laju pertumbuhan harian tidak berbeda antar perlakuan yang diberi penambahan tomat. Laju pertumbuhan mengalami peningkatan seiring dengan peningkatan pemberian tomat. Hal ini membuktikan bahwa tomat berperan dalam peningkatan pertumbuhan ikan (Effendie, 1997).

Sesuai pendapat Lovell menyatakan bahwa, sayuran yang mengandung nilai vitamin yang tinggi berfungsi untuk meningkatkan pertumbuhan normal, mencegah kelainan bentuk tulang, kesehatan benih atau mengurangi stress mempercepat penyembuhan luka dan meningkatkan pertahanan atau kekebalan tubuh melawan infeksi bakteri. Masumoto et al. (1991) mengatakan bahwa, tomat dapat meningkatkan absobsi zat besi dari usus yang 
berperan dalam peredaran oksigen dalam tubuh dan pembentukan kolagen. Prijono dan Toni (1999) menyatakan bahwa, tomat berperan penting dalam biosintesis karnitin dalam jaringan tubuh. Karnitin memegang peranan penting dalam transpor asam lemak ke dalam mitokondria dan asam lemak di oksidasi untuk menghasilkan energi. Terhambatnya pembentukan kalogen akan menyebabkan jaringan pelekat melemah.

Diperjelas oleh Ikeda (1990) bahwa kekurangan vitamin pada sayuran dalam jaringan akan menyebabkan berkurangnya produksi energi dan melemahnya tubuh selain itu dapat menyebabkan terjadinya pertumbuhan tulang yang tidak sempurna, sedangkan menurut Miyasaki et al (1995) Sayuran yang mempunyai nilai komposisi yang tinggi juga dapat mencegah terjadinya metabolisme lemak yang abnormal, seperti berkurangnya kadar asam lemak rantai panjang dan terganggunya penggunaan lemak tubuh selama tidak makan.

Survival rate atau biasa dikenal dengan SR adalah merupakan indeks kelulushidupan suatu jenis ikan dalam suatu proses budidaya dari mulai awal ikan ditebar hingga ikan dipanen.

Nilai tingkat kelangsungan hidup tertinggi secara berurutan adalah P3(93,33\%), P2(93,33\%), P1 (86,66\%), serta P0(46,66\%). Menurut Effendie (1992) menyatakan bahwa, kelangsungan hidup suatu organisme dipengaruhi oleh dua faktor, yaitu faktor biotik yang terdiri dari kompetitor, kepadatan populasi, umur dan kemampuan organisme dengan lingkungan, sedangkan faktor abiotik terdiri dari suhu, oksigen terlarut, $\mathrm{pH}$ dan kandungan amoniak.

Kenyataan ini sesuai dengan hasil penelitian Yurisman, Sukendi dan Putra (2009) menyatakan bahwa, pemeliharaan benih ikan tapah (Wallago $s p$ ) dalam kolam yang diberikan happa dengan padat tebar 6 ekor/happa ditempatkan di kolam dan setelah pemeliharaan selama 3 bulan nilai kelulushidupannya $100 \%$ (ikan tidak ada yang mati). Hal yang sama juga didapatkan pada pembesaran benih ikan motan (Sukendi, Putra, dan Yurisman, 2010) menyatakan bahwa, teknologi budidaya/pembesaran benih ikan motan yang terbaik adalah pemeliharaan dengan padat tebar 10 ekor/happa ukuran $1 \mathrm{x}$ 1 x $1 \mathrm{~m}$ yang ditempatkan di kolam, dan kelulushidupan sebesar $100 \%$.

\section{KESIMPULAN}

Ekstrak tomat yang ditambahkan ke dalam pakan buatan dapat meningkatkan pertumbuhan dan kelangsungan hidup benih ikan tawes (Puntius javanicus).

\section{DAFTAR PUSTAKA}

Amri, K., dan Khairuman. 2008. Buku Pintar Budidaya 15 Ikan Konsumsi. Agro Media Pustaka. Jakarta

Andayani, S. 2005. Manajemen Kualitas Air. Penerbit Brillian Internasional. Surabaya. 75 - 95 hal.

Angriani, R., Iskandar dan A. Taofiqurohman. 2012. Efektifitas Penambahan (Bacillus sp.) Hasil Isolasi dari Saluran Pencernaan Ikan Patin pada Pakan Komersil Terhadap Kelangsungan Hidup dan Pertumbuhan Benih Ikan Nila Merah (Oreochromis niloticus). [Skripsi]. Fakultas Perikanan dan Ilmu Kelautan Unpad, Bandung, V (3) 75-83

Ardiwinata, R. O. 1981. Pemeliharaan ikan tawes. Penerbit Subur Bandung, Bandung

Barades, E. 2008. Pembenihan Ikan Batak (Tor soro) di Instalasi Riset Perikanan Budidaya Air Tawar Bogor Jawa Barat. Usulan Praktik Umum. Universitas Lampung. Bandar Lampung.

Bardach, J.E., Ryther and W. O. Mclarney. 1972. Aquaculture. Wiley Interscience, $104 \mathrm{p}$.

Britner, A., E. Omar, A.M. Nour. 1989. Budidaya Air. Jakarta: Yayasan Obor Indonesia.

Cahyono, B. 2008. Tomat: Usaha Tani dan Penanganan Pascapanen. Kanisius, Yogyakarta

Cholik, F., Jagatraya, A.G., Poernomo, R.P., dan Jauzi, A. 2005. Akuakultur Tumpuan Harapan Masa Depan Bangsa. PT. Victoria Kreasi Mandiri. Jakarta.

Cholik, F. et al. 2005. Akuakultur. Masyarakat Perikanan Nusantara. Taman Akuarium Air Tawar. Jakarta.

De Robert, A., K. William. 2008. Weightlegth relationship in fisheries studies: the standard allometric model should be applied with caution. Transaction of the American Fisheries Society, 137: 707719. 
Desai, V.R. 2003. Synopsis of Biological Data on The Tor Mahseer Tor soro (Hamilton) from River Namada. FAO Fisheries Syopsis.

Djajasewaka. 1985. Nutrisi Ikan. Penerbit Penebar Swadaya. Jakarta. 100 - 140 hal

Efendie, M. I. 1979. Metode Biologi Perikanan. Penerbit Dwi Sri Bogor.

Effendie, M. I. 2002. Biologi Perikanan. Cetakan Kedua/Edisi Revisi. Yayasan Pustaka Nusantara. Yogyakarta. P.163.

Effendi. 1997. Biologi perikanan. Fakultas Perikanan, Institut Pertanian Bogor, Bogor.

Fujaya, Y. 2004. Fisiologi Ikan Dasar Pengembangan Teknik Perikanan. Cetakan pertama. Rineka Putra. Jakarta.

Hanifiah. 1991. Dasar - dasar Ilmu Statistik. Jakarta. Raja Grafindo Persada.

Haryono. 2006. Aspek Biologi Ikan Tambra (Tor tambroides Blkr.) yang Eksotikdan Langka sebagai Dasar Domestikasi. Pusat Penelitian Biologi, Lembaga Ilmu Pengetahuan Indonesia. Bogor. $J$ Biodiversitas. 7(2):195-198.

Haryono. 2007. Tambra, Ikan Kancra dari Pegunungan Muller. Lembaga Ilmu Pengetahuan Indonesia.

Havler, J.E. 1988. Fish Nutrition. School of Fisheries University of Washington, Washington USA, $275 \mathrm{pp}$.

Kordi, K. 2004. Manajemen Kualitas Air Deras. Penerbit Kanisius. Yogyakarta. $64-82$ hal.

Kordi dan Andi. 2009. Manajemen Kualitas Air Untuk Ikan Air Deras. Penerbit Penebar Swadaya. Jakarta. $114-125$ hal.

Krismono. 2006. Ikthiologi Mengenai Ikan. Penerbit Sri Bogor. 102 - 116 hal.

Lesmana. 2001. Manajemen Kualitas Air Untuk Ikan Budidaya. Penerbit Penebar Swadaya. Jakarta. 112 - 142 hal.

Lovell, T. 1988. Nutrition and Feed of Fish. Book van Nostrand reinhold, New York, $261 \mathrm{pp}$.

Masduqi. 2009. Manajemen Kualitas Air. Penerbit Kanisius. Yogyakarta. $20-29$ hal

Mujiman. A. 2000. Pakan Ikan. Penerbit Sri Bogor.

Mudjiman. 2000. Makanan Ikan. Jakarta: CV Simplex.
Mulyadi, M. T. Usman dan Suryani. 2010. Pengaruh Frekuensi Pemberian Pakan yang Berbeda terhadap Pertumbuhan dan Kelulushidupan Benih Ikan Selais (Ompok hypothalmus). Berkala Perikanan Terubuk., 38(2) 21-40.

Nontji. 1989. Laut dan Perairan Indonesia. Penerbit Penebar Swadaya. Jakarta. 213 -230 hal.

Rejeki, S. 2001. Pengantar Budidaya Perairan. Badan Penerbit UNDIP, Semarang

Rypel, A.L., T.J. Richter. 2008. Emperical percentile standard weight equation for the Blacktail Redhorse. North American Journal of Fisheries Management, 28: 1843-1846.

Sanoesi, E., S. Andayani, dan M. Fajar. 2002. "Introduksi Pemanfaatan Silase Ikan Rucah sebagai Bahan Pakan terhadap Pertumbuhan dan Kelulusan Hidup Ikan Kerapu Macan (Ephynephelus fuscoguttatus)". Jurnal Ilmu-ilmu Hayati. 14(I):84-93.

Susanto, H. 2000. Usaha Pembenihan dan pemberantasan ikan tawes. Penebar Swadaya, Jakarta

- H. 2003. Usaha Pembenihan Dan Pembesaran Tawes. Penebar Swadaya. Jakarta.

Suwirya, K., M. Marzuqi dan N.A. Giri. 2003. Pengaruh Vitamin C dalam Pakan terhadap Pertumbuhan Juvenil Kepiting Bakau (Scylla paramamosain). [Skripsi]. Prociding Penerapan Tekhnologi Tepat Guna dalam Mendukung Agribisnis. Balai Besar Riset Perikanan Budidaya Laut Gondol, Bali, 6 hlm.

Ros-Chumillas, M., Belissario, Y., Iguaz, A., dan Lopez, A.2010. Quality and Shelf Life of Orange Juice Aseptically Package in PET bottles. Technical University of Cartagena, Agricultural Equipment and Food Engineering Department.

Yani T \& Ade Iwan S. 2004. Tomat: Pembudidayaan Secara Komersial. Penebar Swadaya. Jakarta. 